This is a self-archived version of an original article. This version may differ from the original in pagination and typographic details.

Author(s): Colli, Andrea; Nevalainen, Pasi

Title: State-owned enterprises

Year: 2020

Version: Accepted version (Final draft)

Copyright: (C) The Contributor(s) 2020

Rights: In Copyright

Rights url: http://rightsstatements.org/page//nC/1.0/?language=en

Please cite the original version:

Colli, A., \& Nevalainen, P. (2020). State-owned enterprises. In T. da Silva Lopes, C. Lubinski, \& H. J. Tworek (Eds.), The Routledge Companion to the Makers of Global Business (pp. 294-311).

Routledge. https://doi.org/10.4324/9781315277813-19 


\section{State-Owned Enterprises}

\section{ABSTRACT}

Globalization has had a decisive impact on state-owned enterprises: national monopolies have largely disappeared, barriers to competition have diminished and business has become international. With the major change in the environment, state-owned enterprises have not disappeared but have adapted themselves to international business standards and practices. Some have taken the opportunity and expanded their operations to international markets. We call these state-owned multinationals (SOMNEs).

In the following chapter we analyze how the originally nationalistic basic idea of state-owned enterprise (SOE) has turned upside down. We seek an explanation for this process from three perspectives: the liberalization of the international markets, the developments in corporate governance practices, and the SOEs' own renewal. These factors at different levels have affected the SOEs' ownership, organization and strategy. As will be shown in the Italian and Finnish cases, corporate governance began to emphasize professionalism and business requirements.

The rise of the State-owned multinational is particularly relevant not only as regards international business. Although the common denominator is the role of the state as an owner, the companies are different. State-owned multinationals are indeed increasingly seen as potentially relevant instruments of political economy, sometimes used by their own governments for geopolitical purposes.

\section{INTRODUCTION}

State-owned enterprises (SOEs) are often considered to be relics of the 20th century history. They are understood as vanishing entities, soon rendered obsolete by the privatization policies of the 1980s and 1990s (cf. Toninelli 2000). Nonetheless, SOEs continue to exist in the most advanced countries (Christiansen 2011), and represent a growing factor in the international market (OECD 2015). Their relevance among the world's largest multinational 
enterprises (MNEs) is significant. Today, $15 \%$ of the world's largest multinational enterprises (MNEs), or $40 \%$ in emerging economies, are under the legal ownership of their home countries' governments (UNCTAD 2017). Our claim is that this development emerged from a fundamental change in the basic concept of the SOE.

The transformation in the basic concept of SOE is closely linked to two major recent developments in Western capitalism. The first was a worldwide process of dismantling the state-owned enterprise system, which had historically characterized Western industrial capitalism after the Second World War (Toninelli 2000; Amatori, Millward, \& Toninelli 2011) and a number of other countries in Asia and Latin America (Musacchio \& Lazzarini 2014). The second was the simultaneous acceleration of globalization after the fall of the Berlin Wall in 1989, and its impact on the internationalization of business enterprises (Colli 2016; Fitzgerald 2016). Research so far has tended to see these two as largely separate phenomena. Our key point is instead that there is a firm relationship between the privatization and the internationalization of the former State-Owned Enterprises.

The literature has long stressed the connection between privatization and liberalization as well as the internationalization of privatized incumbents. Privatizations put the former state-owned assets in the "right" hands of private investors, largely motivated by the logic of economic efficiency, with a positive impact on the companies' internationalization. Recent research has challenged this perspective, finding a much more complex relationship between the ownership dimension of former "national champions" and their internationalization.

Even today, the attitude towards direct state involvement is mixed. "Traditional" SOEs (that is, those active as natural monopolies), are generally considered to be bureaucratic and inefficient organizations. Although common sense tends to emphasize the problems of state entrepreneurship in terms of efficiency, in some cases companies under the control of national governments have internationalized more successfully than those fully privatized - thanks mainly to the state's guiding role in the process (Colli et al. 2014). In the meantime, SOEs have become increasingly relevant in the international economy. The UNCTAD World Investment Report (2017) identified 1,500 state-owned 
multinational enterprises (SOMNEs) with more than 86,000 affiliates. Recent decades have seen the internationalization of traditional SOEs, but also the growth of emerging economies, where SOEs very often play a major role.

There were two major drivers of the revival of SOEs. The first was the transformation of the basic concept of state-owned enterprise. Both in developed and developing countries, states have largely abandoned the idea of total control over "domestic monopolists" in charge of pursuing social and redistributive goals instead of economic ones. This perspective has progressively evolved into a concept of SOE built around the idea of partial state ownership coupled with economic efficiency. The pursuit of economic efficiency implied, of course, access to other markets than the domestic one.

A second driver was the liberalization of domestic markets. When liberalization forced SOEs to face competition in the home market, they were forced to seek new business from the international market. In these contexts, we must not forget the changes that have taken place in SOEs themselves. As a result of external factors, SOEs renewed their own practices, developed internationalization strategies and became part of globalization. Sometimes they became change factors themselves.

In the following sections we examine the process of change in the concept of state-owned enterprise and their impact in the making of global business. As we are looking at a global phenomenon, we define SOE and SOMNE according to the three most basic features. The changes in this model are examined at three different levels: international, corporate governance and firm perspectives. The different levels of change had different characteristics. From our empirical standpoint point of view, we look at two advanced European countries, Italy and Finland, where state operations played a major role in the modernization process of the 20th century and where the role of the state as an owner has changed dramatically. However, as we will see in recent debate, state ownership still has many faces. Even if we finally draw our conclusions into a simplified model, we want to emphasize that the variety of SOEs is still manifold. 


\section{THE THREE DEFINING ELEMENTS OF STATE OWNED MULTINATIONALS}

The traditional state-owned enterprise was established and developed in a variety of circumstances. This is why the definition and corporate structures differ from country to country (e.g. Millward 2011; Christiansen 2011). In general, the definition of SOE relies on state ownership and control, elements that are related but not the same. This very basic attribute has a major impact on state-owned enterprises' other basic characteristics as depicted in Figure 1.

Figure 1. The determinants of state-owned multinational enterprise in three dimensions

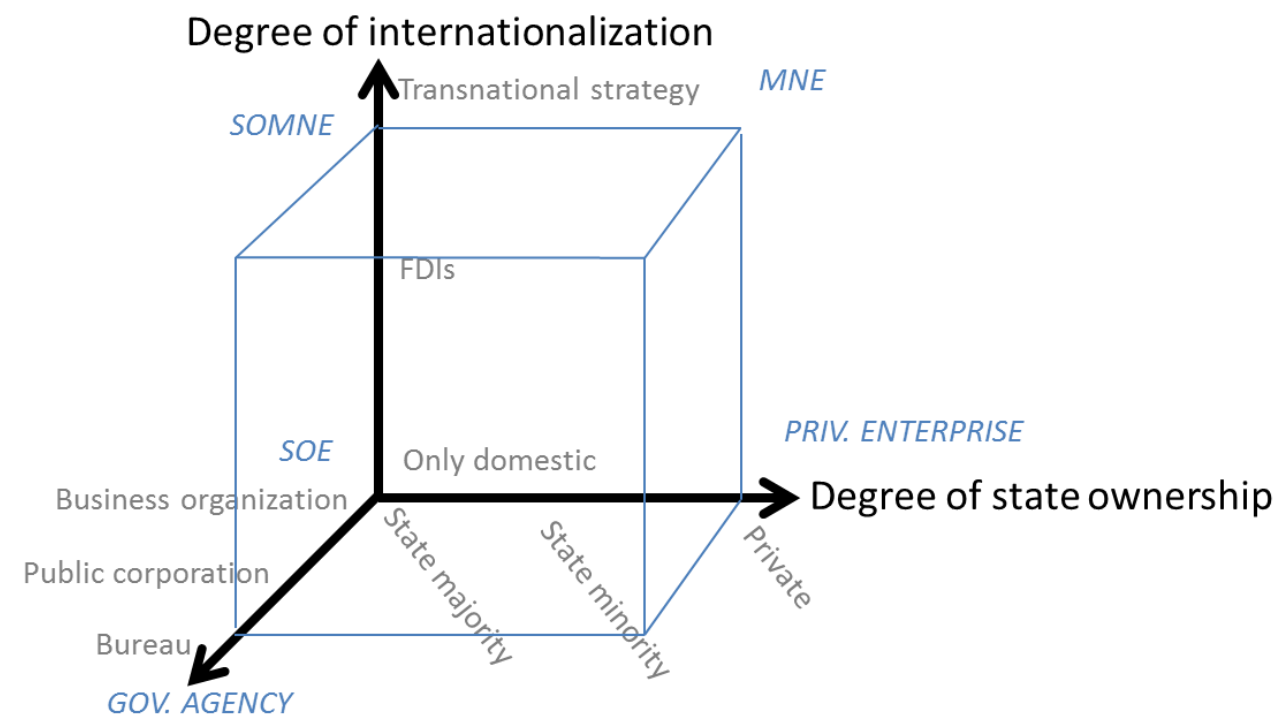

Type of organization

Source: the authors.

These interconnected determining factors, as illustrated in Figure 1, are 1) the degree of state ownership, 2) the type of SOE organization, and 3) the degree of SOE internationalization strategy. The first two, ownership and type of organization are, above all, associated with the general modernization of the SOE. The degree of an SOE's internationalization, in turn, is linked to the emergence of state-owned multinational SOMNE. 
Although our definition for SOE/SOMNE remains broad (within the transparent box in Figure 1), it allows us to conceptualize the transformation from "oldschool" SOEs to SOMNEs. In practice this has often meant moving from the bottom left (government agency) to the upper right corner (multinational enterprise). Generally, development from traditional SOE to modern SOMNE has taken place between these two extremes. The historical trajectory has mostly occurred gradually and usually on one dimension at a time - or at least the development can be analytically distinguished in this way. The general, though debatable, view of the passage has gone so that SOEs are first incorporated and only then privatized, after which they have become internationalized.

State ownership varies between complete, majority, and minority holding. How much of the holding would suffice for the company to be defined as "stateowned" varies. Typically, a state-owned enterprise is a company in which the government holds a simple majority of the ownership rights. Seldom, however, does even a minority fraction suffice to give the state significant influence. For this reason, international comparative databases tend to define companies as SOEs also when the state's holding is very small. Ownership is closely related to control, and, for traditional SOEs in particular, this means a close interconnection with the national government.

SOEs have assumed various organizational forms: government agencies, intermediaries between the agency and the business enterprise, and stateowned limited liability companies (Millward 2005: 188). Especially those in a monopoly situation may also have had official duties, which is why separating them from other state organizations is not always straightforward. Because of this contradiction, they have sometimes been called "hybrid organizations" (Bruton et al. 2015; Aharoni 2018). In recent decades many SOEs have been corporatized and corporations have been directed towards "normal" business organizations whose official duties have most often been discontinued. In the same context, the sole purpose of the companies is to produce a profit. Business historians often associate this development with the emergence of the competitive market; but scholars of administration associate this development with the change in governance thinking. Either way, this shift often represents the generalization of market-oriented thinking, separating SOEs from the state's 
administrative functions, and has often proved an intermediate stage towards privatizations (e.g. Christensen \& Pallesen 2001).

An important concept of multinational enterprise (MNE) is often defined on the basis of company's foreign investment activity (FDIs) (Dunning \& Lundan 2008). In the case of SOEs, a relatively small amount has been enough to meet the criteria of state-owned multinational enterprise (SOMNE). For example, for Anastassopoulos et al. (1987:25), a mere 10 percent of turnover from abroad and operations in at least three countries was sufficient. This definition is particularly well suited for traditional SOEs whose internationalization was related to the acquisition of resources and the establishment of sales offices. In our view, however, internationalization should be understood as a strategic choice.

As Wilkins (2001: 6) recalls, a multinational enterprise provides "a tissue that unifies on a regular basis; it is not merely a channel for one time transactions but a basis for different sorts of external organizational relationships." Ghoshal and Bartlett (1998) divide the multinationals according to how internationalism is reflected in the company's strategy: does internationalization mean "only" the acquisition of resources and sales offices, or whether production or even strategic functions are decentralized across the globe, allowing the MNE to utilize various resources across borders and to specialize in managing value chains (also Aharoni \& Ramamurti 2008). As we will see, such a change from national to multinational, especially when internationalization means a farreaching transnational strategy, challenges the original idea of SOEs as tools for national purposes (Cuervo-Cazurra 2018). To understand the profundity of this change, we begin our historical analysis from the state-owner's original interests.

\section{HOW A FAITHFUL SERVANT BECAME A BURDEN}

The traditional state-owned enterprise was a national creation. Although some of them were established centuries ago (e.g. royal armories, mines, posts, and railways), their significance peaked during the twentieth century, when Europe went through the Second Industrial Revolution. According to Millward (2011; 2013), SOEs were instruments for promoting social and political unification, 
ensuring national defense and achieving economic growth. Basically, traditional SOEs can be divided into infrastructure and industrial facilities with differing purposes. Manufacturing-related SOEs were linked to nations' industrial strength (like machine shops, shipyards), while infrastructural enterprises (like energy and telecommunications) were chosen over other means (regulation, subsidies to private operators) to speed up construction processes or to avoid excessively high subsidy levels and to ensure necessary safety (Millward 2013; Toninelli 2000).

The behavior of SOEs reflected the quality and nature of governments, and their geopolitical situation. "Resource nationalism" is represented among other things by the national oil companies, whose task has been to ensure that the natural resource benefits remain in the home country (Stevens 2008). The defense aspects were particularly visible in network industries, which were partly designed for strategic considerations and security of supply, for which reason nature-based synergies between neighboring regimes (especially between the East and West) remained largely unexploited (Högselius et al. 2016). In addition, in their country, SOEs had often a special political role as significant employers. Sometimes these were accompanied by significant national feelings. Such examples illustrate the fact that in the original concept of SOE, the economic efficiency could easily be overridden by political, military and ideological objectives. On the other hand, when looking at the behavior of these companies in the longer term, it should be remembered that they also developed their own business from their own perspectives. After they were established, their activities developed, expanded and extended to new areas which in many cases had little to do with the state's original purposes (e.g. Aharoni 2018).

The typical state-owned company had a certain built-in inconsistency. Since they were also at least partly business enterprises, they often had to balance between contradictory goals: to be profitable businesses and to accomplish political tasks. Partly because of this, they seemed inefficient in both respects (Heath \& Norman 2004). Although the importance of financial targets grew markedly, the general public drew attention to the often impaired service level. Although the typical public critique associated with them has sometimes been one-sided or exaggerated, it has had a major impact on their public 
image and hence the attitudes of the politicians responsible for the corporate governance of these companies (e.g. Aharoni 2000; Millward 2011).

The "Golden Age" of state-owned companies had begun in some European countries even before the Second World War. They generally reached their greatest significance during the decades immediately after the war, and public criticism of them increased as the post-war economic growth dissipated. The turn, which is usually in the late 1970s, was clear (e.g. Toninelli 2000; Millward 2005). In Europe, Margaret Thatcher's reforms in the UK represented the first systematic agenda for shrinking the public sector, providing relevant benchmarks for other countries (Parker 1999; Musacchio and Lazzarini 2014: 41-43). In fact, privatizing and opening up competition in its different forms progressed in Europe at different speeds, depending, inter alia, on countryspecific political institutions (e.g. Thatcher 2004). In Finland, to take an example, the multi-party system, together with a strictly regulated legislative framework, practically prevented such dire turn of economic policy as that seen in the UK (see Nevalainen 2014: 155). Instead, reforms progressed gradually.

Earlier research has identified different levels of external factors that have been used to explain the change. We divide these into the following categories:

1) Supranational phenomena such as evolving technology (which weakened the foundations of old natural monopolies) and the increased popularity of neoliberal economics (perceiving state intervention as a major disturbance to the market ${ }^{1}$ )

2) The impact of international cooperation within organizations like the OECD, World Bank and the European Community (agreements on the dismantling of barriers to trade)

3) National level policies, involving a number of decision-making levels, such as politics, government administration, and the influence of private companies (that finally led to deregulation efforts and changes in corporate governance policies at the national level, most prominently corporatization and privatization)

\footnotetext{
${ }^{1}$ On public choice theory, agency theory, new economics of regulation and monetarism see Parker 2009: 1222.
} 
State-owned companies themselves wanted to cope with the change and thus become competitive business ventures

\section{SOES AS AN ISSUE FOR THE FREE TRADE MOVEMENT}

International organizations began to be more negative about SOEs as of the late 1980s. This in turn had a great impact as the organizations, with their recommendations and norms, guided the world's states to adhere to the same basic principles, the most important of which was to remove barriers to trade. An important context was of course the Uruguay Round, the 123-nation negotiations that began in 1986 and led to the establishment of the World Trade Organization (WTO) in 1995. The elimination of barriers to trade highlighted the need to improve the efficiency of domestic markets. The term "Washington consensus" was introduced in 1989 to refer to the Washington-based institutions' commonly shared advice to developing countries, especially Latin America, for recovering from the economic crises of the 1980s (Williamson 2004). These usually ineffective SOEs were advised to privatize. This was repeated in the World Bank's (1995) publications, as according to "Bureaucrats in Business," inefficient SOEs slowed down the eradication of poverty.

The most interesting change from the standpoint of traditional SOEs occurred on the "old continent", the traditional core area of state capitalism. The European Commission, which had previously tolerated national solutions, changed its point of view. According to Parker (1999: 23) a particularly important turn was the Single European Act in 1986, which aimed at dismantling barriers to free trade within the EC by the end of 1992. As previously public goods were protected from competition the EC applied pressure to Member States to open up competition in utility markets. In various industries, these developments progressed typically in stages, for example, Thatcher (2001) divided the EC's telecommunications policy change into three main phases: entry into regulation (1979-87), substantial but limited liberalization and re-regulation (1987-92), and the extension of the regulatory framework across the entire sector (19932000). The EC considered the single market a means to compete in a globalizing market. 
Although the trend in recent years has been a decline in state ownership, especially in Western countries, in a global review more than half of multinational state-owned companies are still majority state-owned (Figure 2).

Figure 2. General trends in state capitalism and ownership of state-owned multinationals in 2015

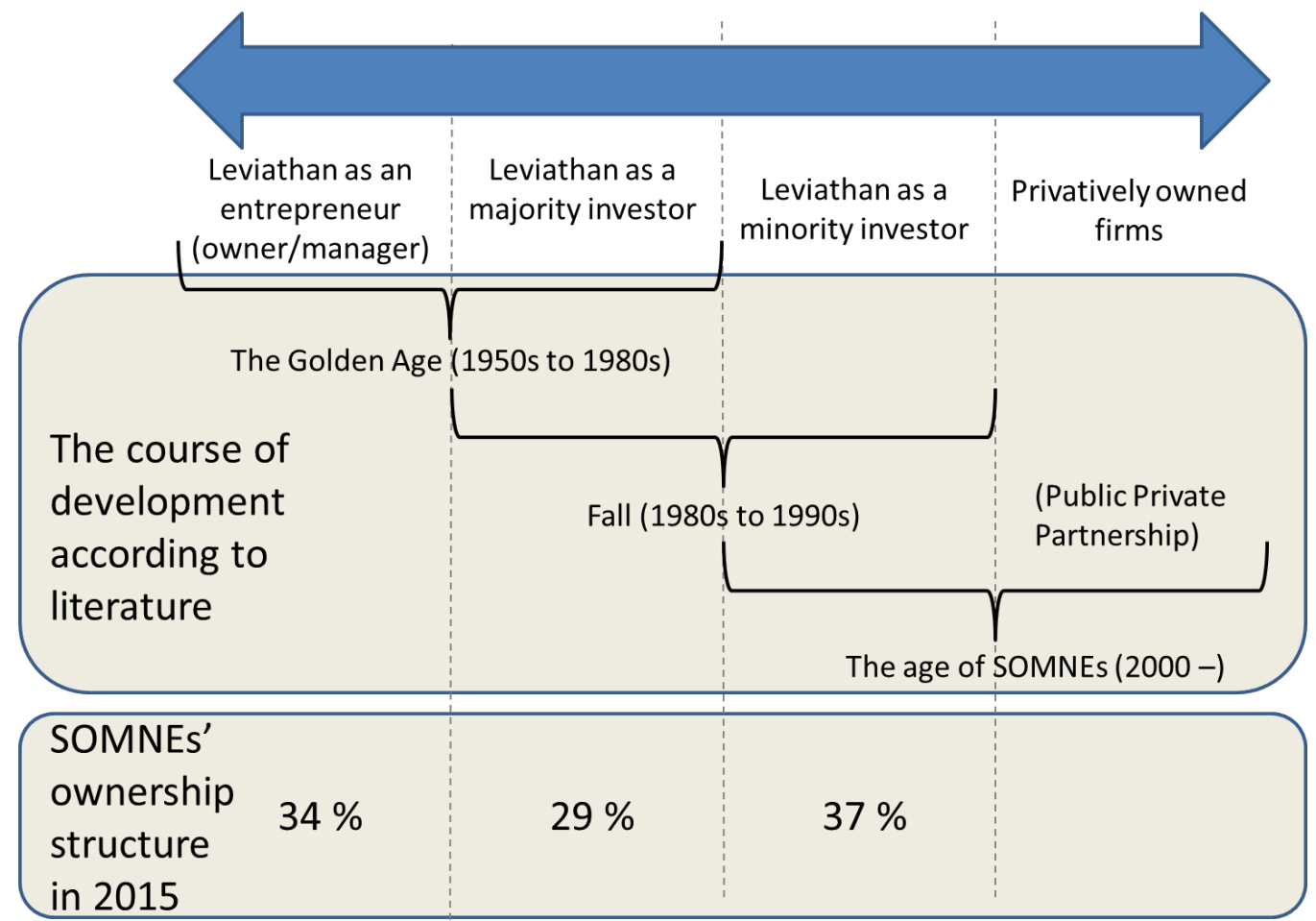

Source: Elaborated on Musacchio \& Lazzarini (2014: 8); UNCTAD (2017:37).

Note: In the overview of international and international companies, it should be remembered that a large number of SOEs are domestic service establishments.

\section{INTERNATIONALIZATION AND CORPORATE GOVERNANCE}

As a consequence of these factors, governments in general changed their attitude to natural monopolies and state ownership and control. Moon (1999) has divided states' new business-oriented approaches into contractual entrepreneurship (incl. government franchises, privatization, cross-services, and contracting out) and managerial entrepreneurship (improved performance with respect to organizational products, processes, and behaviors). 
At the same time as politicians adopted more market-liberal thoughts, the state administrations gradually adopted the ideas of New Public Management (NPM), according to which market-based models borrowed from the private sector were means to solve public sector's contemporary efficiency problems. Unlike previous models aimed at improving administrative efficiency, NPM, despite its alleged neutrality, relied heavily on certain neoliberal perspectives (e.g. Pollitt \& Bouckaert 2011). Deregulation was, according to this thinking, a means of exposing formerly protected industries to market mechanisms, which was believed to increase the efficiency of both the market and of SOEs. In this respect, privatization and deregulation actually served the same purpose.

It is clear that privatization had sometimes its own ideological or instrumental value, such as bringing money into the state's coffers or moving public spending and borrowing off-budget, for example to meet the Maastricht criteria to join a single currency. For governments, privatization was also a way of reducing risk when former state-owned monopolies were exposed to market forces (Parker 1999; Christiansen 2013).

As a result, SOEs faced momentous changes both in their relationships with the political system and in the competitive scenario. Natural monopolies, for which SOEs were often created, were broken piece by piece. In the telecommunications sector (as in many areas, such as public broadcasting), technology, especially wireless digital solutions, dismantled the monopoly of the old public networks. Later on, network operators were forced to open their lanes for the use of competitors as well. Electricity generation and distribution is another example where separation of production and network moved the boundaries of "natural monopolies" (Chick 2007:113). Competitors took part in the markets.

While state institutions lost their special role as guarantor of the public interest as the states developed new ways to regulate the markets and "strategic public ownership" lost most of its past importance (Clifton et al., 2011). In some cases, the state opted for funding or becoming an affiliate. In the United States, the practice of setting up privately owned, but government-funded organizational structures has been widely used since the Second World War. Such solutions were originally used in the development programmes of the armaments 
industry, from which they quickly spread to other sectors as well (Radford 2013: 136).

The general discussion has been dominated by privatization, which was most pronounced in the mid-1990s, when up to 600 SOEs were privatized per year all over the world. In the 2000s, the development leveled off; roughly 200 reported cases per year (Musacchio \& Lazzarini 2014: 44; Clifton et al. 2006) even though state functions previously carried out by authorities have been further incorporated into new SOEs. In the OECD area, the share of SOEs declined in comparison to emerging economies. The privatization was most marked in manufacturing, construction, finance, oil, coal, airlines and the non-grid parts of network utilities, such as electricity, train operations, telecommunications, road transport, shipping, and ports (OECD 2013).

Starting from the beginning of the 2000s, the most common legal form of SOE has been the private limited liability company, followed by the joint stock company. According to the OECD (2004), SOEs in the majority of the OECD countries were considered to be the same as any other private company and were subject to the same legislation. With regard to direct ownership, states are often minority shareholders and tend to manage their equity portfolios professionally (Musacchio et al. 2015).

The following Table 1 summarizes the main differences between the "old" and the "new" models. Of course, the distinction between old and new models is both chronological ("old" was prevalent up to the 1990s) and conceptual/strategic ("old" is a model still diffused in many developing economies). Basically, the distinguishing characteristics of a state-owned company have changed significantly in all areas. While this depicts the principle, development is not always so unambiguous.

Table 1. Differences between the old and new models of SOE

\begin{tabular}{|l|l|l|l|l|l|l|l|l|}
\hline & Ownership & $\begin{array}{l}\text { Legal } \\
\text { form }\end{array}$ & Market & Rationale & $\begin{array}{l}\text { Main Corporate } \\
\text { Governance } \\
\text { lssues }\end{array}$ & $\begin{array}{l}\text { Main assets } \\
\text { of top } \\
\text { management }\end{array}$ & $\begin{array}{l}\text { Political } \\
\text { economy goals }\end{array}$ & $\begin{array}{l}\text { Instrument for } \\
\text { international } \\
\text { relations }\end{array}$ \\
\hline $\begin{array}{l}\text { Old } \\
\text { model }\end{array}$ & Full & $\begin{array}{l}\text { Agency; } \\
\text { Joint } \\
\text { Stock } \\
\text { Company; }\end{array}$ & Domestic & $\begin{array}{l}\text { Natural } \\
\text { monopolies; } \\
\text { redistribution; } \\
\text { employment; }\end{array}$ & $\begin{array}{l}\text { Relationship } \\
\text { with political } \\
\text { parties }\end{array}$ & $\begin{array}{l}\text { Political } \\
\text { connections }\end{array}$ & $\begin{array}{l}\text { Yes, limited to } \\
\text { internal } \\
\text { consensus }\end{array}$ & No \\
\hline
\end{tabular}




\begin{tabular}{|c|c|c|c|c|c|c|c|c|}
\hline & & $\begin{array}{l}\text { listed (few } \\
\text { cases) }\end{array}$ & & $\begin{array}{l}\text { regional } \\
\text { development; } \\
\text { consolidation of } \\
\text { strategic } \\
\text { industries; } \\
\text { national } \\
\text { championship }\end{array}$ & & & & \\
\hline $\begin{array}{l}\text { New } \\
\text { model }\end{array}$ & $\begin{array}{l}\text { Partial; } \\
\text { relative } \\
\text { majority; } \\
\text { control } \\
\text { always }\end{array}$ & $\begin{array}{l}\text { Joint } \\
\text { Stock } \\
\text { Company; } \\
\text { Listed } \\
\text { Company }\end{array}$ & $\begin{array}{l}\text { Internatio } \\
\text { nal }\end{array}$ & $\begin{array}{l}\text { Profitability; } \\
\text { international } \\
\text { vertical } \\
\text { integration; } \\
\text { international } \\
\text { championship }\end{array}$ & $\begin{array}{l}\text { Relationship } \\
\text { with minority } \\
\text { shareholders }\end{array}$ & $\begin{array}{l}\text { Professional } \\
\text { skills and } \\
\text { international } \\
\text { connections }\end{array}$ & $\begin{array}{l}\text { Yes, both for } \\
\text { internal } \\
\text { consensus but } \\
\text { for } \\
\text { international } \\
\text { standing, } \\
\text { supporting } \\
\text { international } \\
\text { relations }\end{array}$ & Yes \\
\hline
\end{tabular}

Source: the authors.

Existing state-owned companies are structurally different from the old ones: we look at this distinction from the viewpoint of corporate governance and the strategies chosen by SOEs. Both these areas have been greatly transforming under the pressure of globalization, and in many cases the result has been the present form of State ownership, no longer based on full ownership of domestic natural monopolies or national champions in strategic industries, but on the partial ownership of global players active at the international level. The internationalization of SOEs is, moreover, raising a number of issues both in the realm of political economy and international relations.

\section{EMPIRICAL PERSPECTIVES ON CORPORATE GOVERNANCE CHANGE}

In the following, we examine the emergence of the "new" model in light of two national cases emphasizing different aspects of the change. Finland and Italy are examples of countries that were rapidly industrialized in the twentieth century with a high level of governmental involvement in the modernization. In both cases the government changed their ownership policies strongly in response to the requirements of the globalizing economy. In addition to what we have already pointed out, these changes have been prompted by companies' own needs: to maintain market efficiency and profitability, basically enlarging their market strategy embracing internationalization. Although the political needs 
have been separated from everyday action, it is clear that the political and ideological trends have influenced policies and indeed continue to do so.

The Italian experience: from a highly centralized holding structure to an extensive privatization program

In Italy, the formation of a state-owned enterprise system was particularly affected by the lack of private capital (Amatori 1997). In 1933, the Italian state ownership was concentrated in a holding company "Instituto di Riconstruzione Industriale" (IRI) to grant long-term loans to companies affected by the depression and to take over the industrial securities held by the country's major banks. In the absence of economic forces, IRI became a permanent owner. It was forced to provide a unified management of a consistent segment of the national economy. As a result, the Italian system became highly centralized.

The government policy was to create large business groups. For instance, in energy, the state supported the creation of a vertically integrated energy group, the Ente Nazionale Idrocarburi (ENI), a national agency producing and distributing electric energy under monopoly conditions (Amatori \& Colli 2011: 190). At the peak of its expansion in the late 1960s, the Italian system of stateowned enterprises included the most important capital-intensive and mass production industries, ranging from steel to chemicals; infrastructures (ranging from motorways and air transport to telecoms), energy, and several other industries, including food and beverages, mass distribution and, last but not least, banking. The SOEs complex was basically the basis of the Italian postwar economic expansion and modernization, and was increasingly also used to reduce economic inequality between different regions of the country (Colli 2016).

This developmental role, however, was also the basis of a steady decline in one of the pillars of SOEs management, as SOEs tended to prioritize political objectives over economic efficiency and profitability. In the early 1990s, the losses turned public opinion against the SOEs. This, in turn, led to one of the most ambitious and intense European privatization programs, which resulted in the total or partial privatization of entire industries. The goal of the privatization process was not only the improvement of state finances but also the 
enhancement of the economic efficiency of the companies, the introduction of more industrial competition, the enlargement of the stock market and the internationalization of the Italian industrial system. The privatization process also created pressures for the revision of corporate law to give more serious consideration to the protection of rights of minority shareholders than had been the case in the past (Amatori \& Colli 2000).

In addition to these, privatization had an important political goal. Italy wanted to be a major player in the European economic and political unification, starting with the Maastricht Treaty, which meant a need on the one hand to speed up the process of restoring the state's finances and on the other to follow the prescriptions emanating from the European Parliament, especially those concerning the participation of the State in the economic system and the elimination of monopolies in public utilities. However, at the same time as the Italian state retreated from specific sectors, the state's direct intervention in the economy through public enterprises has remained a stable feature (Cló et al. 2015).

The Finnish experience: fragmented ownership and the repetitive development of corporate governance

In Finland, the formation of state-owned enterprises was related, even more clearly than in Italy, to the building of a nation-state and promoting industrialization. In the early twentieth century, SOEs were acquired or set up for very practical reasons, such as to produce fertilizers for inefficient agriculture, to set up domestic armaments production and to build network industries. After the Second World War, Finland consolidated its position as a mixed market economy, joining to the OECD in 1969. Strong economic growth, however, seemed to regress in the mid-1970s, which also marked a significant turn towards market-liberal economic policy. According to Junka (2010), the state's role as an industrialist was understood to have reached its endpoint.

SOEs themselves have faced increasing pressure from globalizing markets since the 1980s and many SOEs expanded abroad. Among companies it was commonly thought that only large players would survive in the globalizing business environment. Whereas in the early 1970s the eight largest SOEs had 
zero foreign affiliates, in 1987 there were already 80, mainly located in Western Europe and North America. ${ }^{2}$ As SOEs needed more capital for investments, the pressure to list SOEs on the stock exchange grew (Ranki 2012). In 1988, the Prime Minister still underlined that listing some SOEs was not privatizing, but giving them an opportunity to gain risk financing from the private capital market (Junka 2010).

Another major line of development was the renewal of the corporate governance system, whose biggest problem was its "facelessness": it was not clear who represented "the state", and who was responsible for what part of the steering. ${ }^{3}$ During the following years, the issue was investigated with a particular emphasis on internationalization. SOEs' corporate structures were to be adjusted as to be consistent with "international practices and standards". As noted by the working group (1995): "Instead of a specific knowledge of social interests, it is becoming increasingly important to have a coherent understanding of international business and related risks" ${ }^{4}$ (also Table 2 ).

Table 2. The objectives and principles of the state's ownership policies in the 1990s and 2000s Finland

Objectives (1990s):

1) To secure companies' access to capital

2) To strengthen capacities and international competitiveness

3) To develop company structures in such a way that the companies develop steadily and are able to create jobs

4) Use the revenue from privatizations to strengthen the economy and the state's finances.

5) Increase the value of state property by incorporating and rationalizing state institutions.

6) To enhance corporate governance by developing management, pursuing
Principles (1990s):

1) The state requires the best possible return on capital

2) The state has long-term objectives, which are carried out taking into account the market conditions

3) The state defines and also takes into account the national interests (like defense)

Principles (2004):

1) Regulation and ownership should be strictly separated

2) All the owners are equal

\footnotetext{
237 were "only" marketing companies, 18 were associated with industrial production, 9 were R\&D facilities, but some were classified as "holding companies". Ministry of Trade and Industry's reports, Finnish National Archives: KTM teollisuusos. Hc:4.

${ }^{3}$ Valtionyhtiölainsäädäntötyöryhmä 1989.

${ }^{4}$ Valtionyhtiötyötyhmä 1995: 16-17, 24.
} 
active policy in dividends, improving incentive systems for management and employees

7) To develop capital markets by activating investors and strengthening domestic ownership
3) There should be a unambiguous division of power between parliament and government

4) Ownership policy belongs to the state, operative decisions to the company

Sources: Published memos: "Valtionyhtiöiden omistajapolitiikkaa selvittänyt työryhmä (1999)"; "Valtion yhtiöomistus (2004)".

The turning points of the ownership policy were characterized by failed projects. In the late 1970s the failure of the state-owned television CRT tube factory "Valco" had a dire impact on the general perception of the state's ability to handle business. The policy of the 2000s was affected by the telecommunications incumbent "Sonera", which was rapidly internationalized in the 1990s and transformed into a SOMNE. The partial privatization of the company in 1998 led to a heated public debate and the creation of the general privatization guidelines. ${ }^{5}$ Interestingly enough, the development of recent decades also started in part from Sonera, which in 2002 was on the verge of bankruptcy after winning the licensing auctions (as a part of a consortium) for third-generation UMTS mobile licenses in Germany and Italy. The public debate asked whether the state - as the largest shareholder - should have prevented such ventures. The State Shareholding and Ownership Act (1368/2007) further defined the division of labor between government and parliament. It was also seen as an instrument in the final separation of the ownership function from regulatory and policy responsibilities. ${ }^{6}$ According to OECD (2011), the reform created a comparatively centralized ownership structure.

\section{INTERNATIONALIZATION STRATEGIES: THE PROS AND CONS OF STATE OWNERSHIP}

With the corporatization process, SOEs became more independent than before and they were relieved of their previous administrative and social obligations. Thus the old problem due to the contradictory objectives was, at least to some extent, removed. In these dynamics, stories of success go alongside blunders.

\footnotetext{
${ }^{5}$ Valtionyhtiöiden omistajapolitiikkaa selvittänyt työryhmä 1999.

${ }^{6}$ VNK omistajaohjausos. annual reports 2007-2008
} 
Some companies have successfully become international leaders maintaining their character as state-owned entities, while others have failed. State ownership has both a useful (e.g. through privileged access to state capital) and a harmful side for the company (e.g. excessively politicized and bureaucratic ownership steering). In general, internationalization has been associated with an improved level of management; and vice versa, internationalization may be a means for corporate management to reduce the strict control of the state owner (e.g. Cuervo-Cazurra 2014).

Anastassopoulos et al. (1987) summarized the key factors that influence SOEs' success in internationalization in two main points: 1) How does the top management organize its relationship with the state - in other words - how much freedom can it get to act as it sees fit; and 2) How well does the management learn to master international business - taking into account that, in addition to the strategy, the organization's business culture needs to be changed.

The existence of SOMNEs generates a series of legitimacy problems. Stateowned enterprises are often seen as a mechanisms set up in order to achieve ideological and political goals, or, worse, to interfere in sovereign countries. For example, they can be used as instruments of foreign policy, or to achieve technological know-how. Sometimes their political goals and non-business motivations do clash with the interests of minority shareholders (CuervoCazurra et al. 2014). Meyer et al. (2014) found that the Chinese SOEs expanding overseas faced different expectations and pressures than private-owned companies. This was attributed to the fact that an SOE is supposed to promote the (often non-financial) benefit of its owner. State ownership may also influence the geography itself of an internationalization strategy so that SOEs operate in their own industries (often in some way strategic) or exploit their own strengths. According to some studies (e.g. Knutsen et al. 2011; Amighini et al. 2013) SOEs are more inclined to invest in politically unstable countries than private companies.

From the private business point of view, SOMNEs are often accused of unfair competition, because their owners prefer them, provide them with financially secured positions or otherwise a loose framework for action. Problematic forms of support include for example direct subsidies, concessionary financing, state- 
backed guarantees, preferential regulatory treatment, exemptions from the antitrust enforcement of bankruptcy rules. For such reasons, privatization was seen as a prerequisite for inward investments, as with the lifting of competition, SOEs could use unfair means to block new entrants (Alonso 2013).

It may not be surprising that privatization has often been considered by scholars to be an outright prerequisite for SOEs' internationalization. According to this line of thinking, privatization and market liberalization were supposed to encourage firms to expand abroad, as companies subject to competition in their domestic markets would look for new potential markets. In this competition, the first movers were supposed to gain an advantage. However, as Clifton et al. (2011) have shown, early privatization was not enough to ensure the success of British Telecom.

The relationship between ownership, privatization, and internationalization has been examined particularly in connection with telecommunications, which was one of the fastest growing industries in recent decades. While the new technologies enabled new kinds of business, the past monopolies were opened to competition, most commonly during the 1980s and 1990s. As a result of the combined effect of many factors, the industry's standards and practices were internationalized in exceptionally fast order (e.g. Thatcher 2004). Telecoms were often the first major privatizations, leading the way to further privatization programs, and turning themselves into international corporations.

Several studies have found that the SOEs' own process of change was gradual and that top management was often active (e.g. Erakovic \& Wilson 2005). For telecom incumbents, it has been repeatedly stated that the long process allowed companies to change their ways of doing business (e.g. Karlsson 1998; Palcic \& Reeves 2010). Many began internationalizing before privatizing. For example, the Finnish telecom incumbent Sonera became international in the early 1990s when it built its own networks in Estonia and Russia. These businesses were seen, above all, as proactive moves to safeguard the company's own domestic interests. However, the privatization in 1998 was clearly related to the fact that international business was seen as increasingly important. At this point Sonera itself found state ownership unpleasant, not only because of various administrative constraints, but also because of the company's reputation (e.g. Nevalainen 2017). After the listing in 1998, the Finnish state 
ownership declined gradually to a minority, until the last shares were sold in winter 2018.

Then there are state-owned multinationals with unequivocal political dimensions. Energy companies, despite the internationalized business environment, have retained significant state ownership. In such cases, state control often takes place in different ways; for example, most of the national oil company governance systems are hybrids of corporate governance, public administration, and regulation (Hults 2012). This has not always prevented them from succeeding. For instance, the case of ENI, the Italian oil company, transformed itself into an international player with significant investments around the world, and even in activities (such as the production of nuclear energy), outlawed in the country of origin.

\section{A REAPPRAISAL? STATE-OWNED MULTINATIONALS IN THE $2010 \mathrm{~S}$}

Despite large-scale privatizations in the 1980s and 1990s and the clearly declining trend in Western countries, SOEs remained as significant actors in particular in network industries and the banking sector. As has already been shown their expansion to the international market is seen both as a threat and an opportunity. Being owned by the state, they can still be used as tools, for example, for the protection of domestic markets (OECD 2013). Therefore the OECD considers it important that business and regulation are clearly distinguished. It underlines the importance of good corporate governance practices. In this regard, the World Bank (2006) also sees potential. Wellmanaged SOEs can serve as examples of good governance in emerging economies.

Table 3. SOMNEs in 2017: Geographic distributions

\begin{tabular}{|ccc|}
\hline European Union & & 420 \\
Sweden & 49 & \\
France & 45 & \\
Italy & 44 & \\
Germany & 43 \\
\hline
\end{tabular}




\begin{tabular}{|c|c|c|c|}
\hline & Belgium & 32 & \\
\hline & Norway* & 32 & \\
\hline & Portugal & 26 & \\
\hline & Slovenia & 24 & \\
\hline & Austria & 23 & \\
\hline & Finland & 23 & \\
\hline & Poland & 21 & \\
\hline & Switzerland & 20 & \\
\hline & Spain & 19 & \\
\hline & Netherlands & 11 & \\
\hline & Croatia & 10 & \\
\hline China & & & 257 \\
\hline Malaysia & & & 79 \\
\hline India & & & 61 \\
\hline South Africa & & & 55 \\
\hline Russian Feder & eration & & 51 \\
\hline United Arab E & Emirates & & 50 \\
\hline Republic of Kc & Korea & & 33 \\
\hline Singapore & & & 29 \\
\hline Quatar & & & 27 \\
\hline New Zealand & & & 24 \\
\hline Canada & & & 18 \\
\hline Egypt & & & 14 \\
\hline Brazil & & & 12 \\
\hline Zimbabwe & & & 9 \\
\hline Japan & & & 6 \\
\hline Colombia & & & 5 \\
\hline TOTAL & & & 1150 \\
\hline
\end{tabular}

SOURCE: UNCTAD World Investment Report 2017: 31.

NOTE: The most important sectors were finance, insurance and real estate (18\%), electrics, gas and sanitary (10\%), transportation (10\%), holdings (7\%), and mining $(6 \%)$.

Especially during the financial crisis (2007-8), it was suspected that SOEs might be making a comeback. Governments rescued some companies that were considered particularly important or "too big to fall" (e.g. banks) (e.g. Stevens 2008; Florio 2013). Sometimes SOEs are still used to overcome obstacles to growth. Sometimes governments retain their holdings in order to avoid the risk of foreign ownership. However, structural changes in Europe have continued in recent years. Efficiency enhancing measures have ranged from modification of the legal framework and corporate governance (including corporatization and 
separation of activities) to selling assets to private parties or full privatizations. Other reforms have aimed at improving transparency and accountability. A recent wave of privatizations or preparatory steps has occurred mainly in the network industries, for example in power grids. According to the European Commission (2016), these efforts have been motivated by public finance constraints and the structural disadvantages that are still associated with state ownership.

While traditional research has focused on European SOEs, their significance has increased significantly with the growing importance of emerging economies, where the range is often also wider than in Europe (Table 3). Of particular importance is China, which in 2010 had the highest share of SOEs among its largest enterprises (Christiansen 2011; OECD 2013). This is also reflected in the focus of the current discussion (Bruton et al. 2015). In recent years, public debate has focused on loss-making, state-owned "zombie companies" that cannot survive without substantial support. Chinese SOEs are often deemed less efficient and innovative than their private counterparts (Girma \& Gong 2008; Girma et al. 2009). The reasons found resemble the content of the European debate: non-commercial objectives and loose budget constraints combined with inefficient management practices are seen to be characteristic (Li et al. 2014) in principle.

\section{CONCLUSION}

State-owned enterprises played a paramount role in the process of catching up and modernization starting from the mid-twentieth century, in Europe, Latin America, India and East Asia. Their pervasiveness reached a peak in the early 1980s. Everywhere governments acted as entrepreneurs in a huge variety of industries, both in manufacturing, and services. Globalization and above all the liberalization climate of the ninety nineties has dramatically transformed the nature of SOEs and their significance in the 'making of global business'.

In this chapter, we have looked at this change from the point of view of the three determinant factors (Figure 1): ownership, corporate governance, and internationalization strategy. These factors we have examined at three levels: international cooperation, national decision-making, and SOEs themselves. In 
Table 4 we summarize how these were related to each other. In the top line, we present features defining SOEs, while on the vertical axis we show how these characteristics were seen at the international, national and corporate level. The table can be read in both directions. Although the phenomenon as a whole is still much more diverse, certain main tendencies are apparent.

Table 4. How the factors determining SOE were seen at different levels

\begin{tabular}{l|l|l|l|} 
& State ownership (SO) & $\begin{array}{l}\text { Corporate } \\
\text { governance (CG) }\end{array}$ & $\begin{array}{l}\text { SOEs' } \\
\text { Internationalization } \\
\text { strategies }\end{array}$ \\
\hline $\begin{array}{l}\text { International layer: } \\
\text { international } \\
\text { organizations }\end{array}$ & $\begin{array}{l}\text { SO was increasingly seen as } \\
\text { a cause of market } \\
\text { disturbance }\end{array}$ & $\begin{array}{l}\text { Since SO was found to be a } \\
\text { permanent phenomenon, } \\
\text { good CG was a way to } \\
\text { counteract abuses }\end{array}$ & $\begin{array}{l}\text { SOEs were feared to be } \\
\text { unfair competitors }\end{array}$ \\
\hline $\begin{array}{l}\text { National layer: } \\
\text { governments }\end{array}$ & $\begin{array}{l}\text { New regulation overrode } \\
\text { SO's original significance }\end{array}$ & $\begin{array}{l}\text { Regulatory and business } \\
\text { functions were separated }\end{array}$ & $\begin{array}{l}\text { Mixed attitude: suspicion } \\
\text { changed to encouragement }\end{array}$ \\
\hline $\begin{array}{l}\text { State-owned } \\
\text { enterprise }\end{array}$ & $\begin{array}{l}\text { Neutral or positive stance } \\
\text { often changed to desire to } \\
\text { become privatized }\end{array}$ & $\begin{array}{l}\text { The general problem was } \\
\text { contradictory objectives; } \\
\text { SOEs intention was to } \\
\text { increase their freedom to } \\
\text { do business }\end{array}$ & $\begin{array}{l}\text { Was sometimes considered } \\
\text { as an outright necessity } \\
\text { with the } \\
\text { internationalization of the } \\
\text { markets }\end{array}$ \\
\hline
\end{tabular}

Source: the authors.

We want to continue to emphasize the importance of the gradual process whose starting point and background lie in economic globalization. Governments opened up markets because competition was seen to boost the economy. SOEs were subject to pressure not only from government but also from the market. When SOEs adapted to the international market, they themselves became multinational enterprises. Companies in which state-ownership remained high became state-owned multinationals. If we look at the basic elements in Figure 1 , it is noteworthy that although mainstream developments have gone from corner to corner (from a state institution to a multinational enterprise), different paths and outcomes are possible. Exceptional combinations are, however, most often seen as anomalies.

This development means a fundamental change in the basic concept of SOE. Where SOEs originally acted as national safeguards against the unpredictable outside world, an international company is a living part of globalization. Although it appears at first sight that little remains of the traditional SOE except 
a thin slice of state ownership, many of the basic elements are still present. Most prominently, suspicions regarding SOMNEs. State ownership and control will be particularly contradictory if it is in the company's interest to adopt a transnational strategy, which means spreading its operations, including strategic functions over several countries. For these reasons, the general expectation is that when SOEs take an international turn, they should abandon their original obligations and eliminate their state-owner's political influence. In part this problem is solved especially in Western countries, such as Italy and Finland, by separating ownership and steering, and reducing state ownership to a minority. This, of course, solves some of the contradictions, but the real significance of state's strong minority ownership remains to be seen.

\section{LIST OF REFERENCES}

Aharoni, Yair (2018), 'The Evolution of State-Owned Multinational Enterprise Theory, in Alvaro Cuervo-Cazurra (ed.), State-Owned Multinationals:

Governments in Global Business (Cham: Palgrave Macmillan), 9-44.

Aharoni, Yair (2000), 'The performance of state-owned enterprises', in: Pier Angelo Toninelli (ed.), The rise and fall of state-owned enterprise in Western World (Cambridge, UK: Cambridge University Press), 49-72.

Aharoni, Yair and Ramamurti, Ravi (2008), 'The Internationalization of Multinationals', in Jean J. Boddewyn (ed.), International Business Scholarship: AlB Fellows on the First 50 Years and Beyond (Emerald), 177-201.

Alonso, José M., Clifton, Judith, Díaz-Fuentes, Daniel, Fernández-Gutiérrez, Marcos and Revuelta, Julio (2013), 'The Race for International Markets: Were Privatized Telecommunications Incumbents More Successful Than Their Public Counterparts?', International Review of Applied Economics, 27 (2), 215-36.

Amatori, Franco (1997), 'Italy: The tormented rise of organizational capabilities between government and families', in Alfred Chandler Jr., Franco Amatori and Takashi Hikino (eds.), Big Business and the Wealth of Nations (Cambridge: Cambridge University Press), 246-76.

Amatori, Franco and Colli, Andrea (2011), Business History: Complexities and comparison (London: Routledge). 
Amatori, Franco and Colli, Andrea (2000), Corporate Governance: The Italian Story (CGEP Working Paper).

Amatori, Franco, Millward, Robert and Toninelli, Pier A. (2011), 'Introduction', in Franco Amatori, Robert Millward and Pier Angelo Toninelli (eds.),

Reappraising State-Owned Enterprise: A comparison of the UK and Italy (London: Routledge), 3-10.

Amighini, Alessia A., Rabellotti, Roberta and Sanfilippo, Marco (2013), 'Do Chinese State-Owned and Private Enterprises Differ in Their Internationalization Strategies?', Chinese Economic Review, 27, 312-25.

Anastassopoulos, Jean-Pierre, Blanc, Georges and Dussage, Pierre (1987), State-owned multinationals, (Chichester: John Wiley \& Sons).

Bruton, Garry D., Peng, Mike W., Ahlstrom, David, Stan, Ciprian, and Xu, Kehan (2015), 'State-Owned Enterprises Around the World as Hybrid Organizations', The Academy of Management Perspectives, 29 (1), 92-114.

Cló, Stefano, DiGiulio, Marco, Galanti, Maria Tullia \& Sorrentino, Maddalena (2015), Italian State-Owned Enterprises After Decades of Reforms: Still Public? (Ciriec Working Paper 2015/19).

Chick, Martin (2007), Electricity and energy policy in Britain, France and the United States since 1945 (Cheltenham: Edgar Elgar).

Christensen, Jørgen and Pallesen, Thomas (2001), 'The Political Benefits of Corporatization and Privatization', Journal of Public Policy, 21 (3), 283-309.

Christiansen, Hans (2013), Balancing Commercial and Non-commercial Priorities of State-Owned Enterprises (OECD Corporate Governance Working Papers No. 6). Retrieved from: http://dx.doi.org/10.1787/5k4dkhztkp9r-en

Christiansen, Hans (2011), The Size and Composition of the SOE Sector in OECD Countries (OECD Corporate Governance Working Papers No. 5). Retrieved from: http://dx.doi.org/10.1787/5kg54cwps0s3-en

Clifton, Judith, Comín, Francisco, and Diaz-Fuentes, Daniel (2011), 'From National Monopoly to Multinational Corporation: How Regulation Shaped the 
Road Towards Telecommunications Internationalization', Business History, 53 (5), 761-81.

Clifton, Judith, Comín, Francisco \& Díaz Fuentes, Daniel (2006), 'Privatizing public enterprises in the European Union 1960-2002: ideological, pragmatic, inevitable?' Journal of European Public Policy, 13 (5), 736-56.

Clifton, Judith, Lanthier, Pierre, \& Schröter, Harm (2011), Regulating and deregulating the public utilities 1830-2010. Business History, 53 (5), 659-72.

Colli, Andrea (2016), Dynamics of International Business: Comparative Perspectives of Firms, Markets and Entrepreneurship (New York: Routledge).

Colli, Andrea, Mariotti, Sergio, and Piscitello, Lucia (2014), 'Governments as Strategists in Designing Global Players: The Case of European Utilities', Journal of European Public Policy, 21 (4), 487-508.

Cuervo-Cazurra, Alvaro (2018), 'State-Owned Multinationals: Introduction', in Alvaro Cuervo-Cazurra (ed.), State-Owned Multinationals: Governments in Global Business (Cham: Palgrave Macmillan), 1-6.

Cuervo-Cazurra, Alvaro, Inkpen, Andrew, Musacchio, Aldo, and Ramaswamy, Kannan (2014), Governments as Owners: State-Owned Multinational Companies, Journal of International Business Studies, 45 (8), 919-42.

Dunning, John and Lundan, Sarianna (2008). Multinational Enterprises and the Global Economy ( $2^{\text {nd }}$ ed.) (Cheltenham, UK: Edward Elgar).

Erakovic, Ljiljana and Wilson, Marie (2005), 'Conditions of Radical Transformation in State-Owned Enterprises', British Journal of Management, 16 (4), 293-313.

European Commission. (2016), State-Owned Enterprises in the EU: Lessons Learnt and Ways Forward in a Post-Crisis Context (Luxembourg: the European Union). Retrieved from: http://ec.europa.eu/economy_finance/publications/ Fitzgerald, Robert (2016), The Rise of the Global Company: Multinationals and the Making of the Modern World (Cambridge, UK: Cambridge University Press). 
Florio, Massimo (2013), 'Rethinking on Public Enterprise: Editorial Introduction and Some Personal Remarks on the Research Agenda', International Review of Applied Economics, 27 (2), 135-49.

Ghoshal, Sumantra and Bartlett, Christopher (1998), Managing Across Borders: The transnational solution (London: Random House).

Sourefel, Girma and Yundan, Gong (2008), 'FDI, Linkages and the Efficiency of State-Owned Enterprises in China', The Journal of Development Studies, 44 (5), 728-49.

Sourafel, Girma, Yundan, Gong and Holger, Görg (2009), 'What determines Innovation Activity in Chinese State-Owned Enterprises? The Role of Foreign Direct Investment', World Development, 37 (4), 866-73.

Hults, David (2012), 'Hybrid governance: state management of national oil companies', in David G. Victor, David R. Hults and Mark Thurber (eds.), Oil and governance: State owned enterprises and the world energy supply (Cambridge, UK: Cambridge University Press), 62-120.

Högselius, Per, Kaijser, Arne and van der Vleuten, Erik (2016), Europe's infrastructure transition: Economy, War, Nature (Palgrave Macmillan).

Heath, Joseph, \& Norman, Wayne (2004), 'Stakeholder Theory, Corporate Governance and Public Management: What can the History of State-Run Enterprises Teach us in the Post-Enron era?', Journal of Business Ethics, 53, 247-65.

Junka, Teuvo (2010), Valtionyhtiöt 1975-2008 [State-owned enterprises 19752008] (Helsinki: Valtion taloudellinen tutkimuskeskus).

Karlsson, Magnus (1998), The liberalisation of telecommunications in Sweden: Technology and regime change from the 1960s to 1993 (Doctoral dissertation) (Linköping: University of Linköping).

Knutsen, Carl, Rygh Asmund and Hveem, Helge (2011), 'Does state ownership matter? Institutions' effect on foreign direct investment revisited', Business and Politics, 13 (1), 1-31. 
Kowalski, Przemyslaw, Büge, Max, Sztajerowska, Monika and Egeland, Matias (2013), State-Owned Enterprises: Trade Effects and Policy Implications. OECD Trade Policy Papers No. 147 (Paris: OECD Publishing).

Li, Shaomin, Lin, Ying Chou and Selober, David (2014), 'Chinese State-Owned Enterprises: Are they inefficient?', The Chinese Economy, 47 (5-6), 81-115.

Millward, Robert (2013), The state and business in the major powers: an economic history, 1815-1939 (London: Routledge).

Millward, Robert (2011), 'Public Enterprise in the Modern Western World: An Historical Analysis', Annals of Public and Cooperative Economics, 82 (4), 37598.

Millward, Robert (2005), Private and public enterprise in Europe: Energy, Telecommunications and Transport, 1830-1990 (Cambridge: Cambridge University Press).

Meyer, Klaus, Ding, Yuan, Li, Jing and Zhang, Hua (2014), 'Overcoming Distrust: How State-Owned Enterprises Adapt Their Foreign Entries to Institutional Pressures Abroad', Journal of International Business Studies, 45 (8), 1005-28.

Moon, Myung Jae (1999), 'The Pursuit of Managerial Entrepreneurship: Does Organization Matter?', Public Administration Review, 59 (1), 31-43.

Musacchio, Aldo, Lazzarini, Sergio G. and Aguileira, Ruth V. (2015), 'New Varieties of State Capitalism: Strategic and Governance Implications', Academy of Management Perspectives, 29 (1), 115-31.

Musacchio, Aldo and Lazzarini, Sergio G. (2014), Reinventing state capitalism: Leviathans in business, Brazil and beyond (Cambridge, MA: Harvard University Press).

Nevalainen, Pasi (2014), Virastosta liikeyritys: Posti-ja telelaitoksen muutosprosessi 1930-1994 [From State Department to Business Enterprise: The Finnish Post and Tele-communications Department and the process of change 1930-1994], Doctoral dissertation (Jyväskylä: University of Jyväskylä).

Nevalainen, Pasi (2017), 'Facing the inevitable? The public telecom monopoly's way of coping with deregulation', Business History, 59 (3), 362-81. 
OECD. (2004), Corporate governance of state-owned enterprises: A survey of OECD countries (Paris: OECD Publishing).

OECD. (2011). State-Owned Enterprise Governance Reform: An Inventory of Recent Change (Paris: OECD Publishing).

OECD. (2015), OECD Guidelines on Corporate Governance of State-Owned Enterprises (Paris: OECD Publishing).

Parker, David (2009), The Official History of Privatisation: The Formative Years 1970-1987 (London: Routledge).

Parker, David (1999), 'Privatization in the European Union: A Critical Assessment of its Development, Rationale and Consequences', Economic and Industrial Democracy, 20 (1), 9-38.

Pollitt, Christopher and Bouckaert, Geer (2011), Public Management Reform: A Comparative Analysis: New Public Management, Governance, and the NeoWeberian State ( $3^{\text {rd }}$ ed.) (Oxford: Oxford University Press).

Radford, Gail (2013), The Rise of the Public Authority: Statebuilding and Economic Development in Twentieth-Century America (Chicago: The University of Chicago Press).

Ranki, Risto (2012), Niin Siinä Käy Kun Omistaa: Tarinaa Valtionyhtiöistä [So it happens when you own: story about state-owned enterprises], (Helsinki: Ministry of Economic Affairs and Employment, Edita).

Stevens, Paul (2008), 'National Oil Companies and International Oil Companies in the Middle East: Under the Shadow of Governments and the Resource Nationalism Cycle', Journal of World Energy \& Law Business, 1 (1), 5-30.

Toninelli, Pier A. (2000), 'The Rise and Fall of Public Enterprise: The Framework', in Pier Angelo Toninelli (ed.), The Rise and Fall of State-Owned Enterprise in the Western World (Cambridge, UK: Cambridge University Press), 3-24.

Thatcher, Mark (2001), 'The Commission and National Governments as Partners: EC Regulatory Expansion in Telecommunications 1979-2000', Journal of European Public Policy, 8 (4), 558-584. 
Thatcher, Mark (2004), 'Varieties of Capitalism in an Internationalized World: Domestic Institutional Change in European Telecommunications', Comparative Political Studies, 37 (4), 751-80.

UNCTAD. (2017), World Investment Report 2017: Investment and Digital Economy (Geneva: United Nations). Retrieved from http://unctad.org/en/PublicationsLibrary/wir2017_en.pdf

Wilkins, Mira (2001), 'The history of multinational enterprise', in Alan M. Rugman and Thomas L. Brewer (eds.), The Oxford handbook of international business (Oxford University Press).

Williamson, John (2004), 'The strange history of the Washington consensus', Journal of Post Keynesian Economics, 27 (2), 195-206.

World Bank (2006), Held by the Visible Hand: The Challenge of State-Owned Enterprise Corporate Governance for Emerging Markets. Retrieved from http://documents.worldbank.org/curated/en/396071468158997475/Held-bythe-visible-hand-the-challenge-of-state-owned-enterprise-corporategovernance-for-emerging-markets

World Bank (1995), Bureaucrats in Business: The Economics and Politics of Government Ownership (New York: Oxford University Press). 